\title{
The expression and significance of IDH1 and p53 in osteosarcoma
}

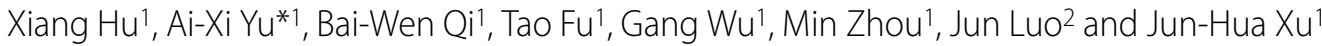

\begin{abstract}
Background: To detect the expression of isocitrate dehydrogenase 1 (IDH1) and transformation-related protein 53 (p53) in osteosarcoma and analyze the correlation between them and the clinico-pathological features.

Methods: The expressions of IDH1 and p53 were detected in human osteosarcoma cell lines (MG-63 and U2OS) by immunocytochemistry, Real-time PCR and Western Blotting. The expressions of IDH1 and p53 in formalin-fixed paraffin-embedded tissue sections from 44 osteosarcoma patients were determined by immunohistochemistry, and the correlation between them and clinicopagthological features were analyzed. None of these patients received chemotherapy prior to surgery.
\end{abstract}

Results: IDH1 is detected in osteosarcoma cell lines and biopsies. IDH1 expresses higher in U2OS cells with wild type p53 than in MG-63 cells with mutation p53. IDH1 correlates with histological Rosen grade and metastasis negatively. P53 correlates with histological Rosen grade, metastasis and overall survival in clinical osteosarcoma biopsies. Osteosarcoma patients with High IDH1 expression have a very high p53 expression.

Conclusion: IDH1 may correlate with p53 and be a candidate biomarker for osteosarcoma correlate with histological Rosen grade and metastasis.

\section{Background}

Osteosarcoma (OS) is the most current primary malignant bone tumor in children and adolescents. Presently, $60 \%$ of the affected patients are cured by wide resection of the tumor and aggressive adjuvant chemotherapy [1,2]. However, around $40 \%$ of the individuals with metastases still emerge which normally exhibit resistance to cytostatics and acquire "second malignancies" [3]. The identification of biomarkers linked to clinicopagthological features and development of this disease is crucial for the diagnosis and treatment of these patients $[4,5]$.

Genetic alterations caused either by lost of heterozygosity or by mutations have been reported in osteosarcoma. Such alterations can occur in tumor suppressor genes, such as tumor protein 53(p53) and phosphates and tensin homolog (PTEN). The p53 mutations occurs commonly in primary osteosarcoma [6]. It is implicated in the pathogenesis of various human malignancies through loss of function mutations [7,8]. P53 contributes to the devel-

*Correspondence: yuaixi666@163.com

1 Department of Orthopedics, Zhongnan Hospital of Wuhan University, No 169 Donghu Road, Wuchang District, 430071, Wuhan, China

Full list of author information is available at the end of the article opment, life expectancy, and overall fitness of an organism except for its role in protecting against cancer development [9]. PTEN is known to be the most highly mutated tumor suppressor gene after p53 [10]. It plays an important role in regulating proliferation, migration, survival, cell invasion and tumor angiogenesis $[11,12]$. Freeman et al. [13] reported that loss of PTEN was a common occurrence in osteosarcoma. It was further demonstrated that PTEN can control p53 half-life independent via a currently unknown mechanism [14]. In addition, mutations of tumor-suppressor retinoblastoma gene $(\mathrm{Rb})$ in osteosarcoma are associated with a poor prognosis [15]. However, none of these alterations can characteristically reflect the biologic nature or clinical features of all osteosarcomas.

IDH1 is a cytosolic NADP-dependent isocitrate dehydrogenase. It catalyzes decarboxylation of isocitrate into alpha-ketoglutarate [16]. Shechter et al. [17] described that the activity of IDH1 is coordinately regulated through the cholesterol and fatty acid biosynthetic pathways, suggesting that IDH1 provides the cytosolic NADPH required by these pathways. Memon et al. [18] found that expression of IDH1 was downregulated in a 
poorly differentiated bladder cancer cell line compared with a well-differentiated bladder cancer cell line. Tissue biopsies of late-stage bladder cancers also showed IDH1 downregulation compared with early-stage bladder cancers. Yan et al. [19] described that mutations of NADP (+)-dependent isocitrate dehydrogenases encoded by IDH1 and IDH2 occur in a majority of several types of malignant gliomas.

Interestingly, Parsons et al. [20] found that IDH1 mutations in human glioblastoma had a very high frequency of p53 mutation. Mutation of the IDH1 gene was also strongly correlated with a normal cytogenetic status [21]. IDH1 appears to function as a tumor suppressor that, when mutationally inactivated, contributes to tumorigenesis $[21,22]$. But, there is no study on the expression of IDH1 in osteosarcoma. As to the previous study on IDH1 and p53, we are also curious intensively about the correlation between IDH1 and p53. So, we developed a study to characterize the expression and significance of IDH1 and p53 in osteosarcoma cell lines (MG63 and U2OS) as well as in clinical patient biopsies.

\section{Methods}

\section{Cell lines and cell culture}

The human osteosarcoma (OS) cell lines MG63 and U2OS (obtained from ATCC through LGC Promochem, Wesel, Germany) were cultured in RPMI 1640 media (Sigma, USA) with 10\% fetal bovine serum (Amresco, USA) and antibiotics. Cells were cultured according to standard techniques in cell culture flasks in a humidified incubator in $5 \% \mathrm{CO}_{2}$ atmosphere.

\section{Immunocytochemistry}

Cell lines were grown on coverslips treated with the appropriate growth media in 24 well cluster plates. Cells were fixed in $2 \%$ formaldehyde in $0.1 \mathrm{~mol} / \mathrm{L}$ phosphatebuffered saline (PBS, pH 7.4) for $20 \mathrm{~min}$ at room temperature and subsequently washed three times in PBS. Coverslips were permeabilized with $0.1 \%$ Triton X-100 for 15 min and blocked in $3 \% \mathrm{H}_{2} \mathrm{O}_{2}$-methyl alcohol for $15 \mathrm{~min}$. The coverslips were incubated with anti-IDH1 rabbit polyclonal antibody (protein technology group, USA) in blocking buffer overnight at $4^{\circ} \mathrm{C}$. Coverslips were then incubated with an anti-rabbit secondary antibody and peroxidase-conjugated strepavidin-biotin complex (Santa Cruz, CA, USA) at $37^{\circ} \mathrm{C}$ for $45 \mathrm{~min}$ at room temperature in the dark [23]. Immunoreactivity was visualized with diaminobenzidine (DAB) (Zymed, South San Francisco, CA). Negative controls were obtained by omitting the primary antibody. Slides were scanned using a microscopy (Carl Zeiss AG, Germany), images were recorded using a digital camera (DC 500, Leica) and the Leica FW 4000 software and images were processed using Adobe Photoshop.

\section{Real-time PCR}

Cellular total RNA from OS cells was extracted with TRIZOL Reagent (Invitrogen, Carlsbad, CA, USA). The concentration of RNA was determined by the absorbance at $260 \mathrm{~nm}$ and the purity was determined by the $260 / 280$ ratio with a BioPhotometer(Eppendorf, Hamburg, Germany). For each reaction, $1 \mu \mathrm{g}$ RNA was reverse-transcribed with random primer by ReverTra Ace (Toyobo, Osaka, Japan). RNA quality and efficiency of reverse transcription were examined by PCRs from each $1 \mu \mathrm{lDNA}$ according to the manufacturer's recommendations [24]. The mRNA expression of IDH-1, p53 and internal control gene $\beta$-actin was quantified by Real-time PCR Detection System (SLAN, HONGSHI) with SYBR Green I (Toyobo, Osaka, Japan). As PCR was performed according to standard procedures $[24,25]$ after optimization, PCR-reactions were within the exponential range of amplification. The gene-specific exon-spanning PCR primer pair for IDH1 was 5'-TCAGTGGCGGTTCTGTGGTA-3',5'CTTGGTGACTTGGTCGTTGGT-3', and for $\mathrm{p}^{53^{7-8}}$ was 5'-CAGCCAAGTCTGTGACTTGCACGTA C-3',5'CTATGTCGAAAAGTGTTTCTGTCATC-3', and for $\beta$ actin was 5'-GTCCACCGCAAATGCTTCTA-3', 5'TGCTGTCACCTTCACCGTTC-3'. The sequences of the primers were checked by Nucleotide BLAST for specific gene amplification. Omission of cDNA template was used as a negative control. Triplicate measurements were made of all genes in each patient and data of mean were used. For relative quantification of genes expression level, standard curves were built by considering at least three points of a ten-fold dilution series of cDNA in water. Relative gene expression data are given as the $\mathrm{n}$-fold change in transcription of the target genes normalized to the endogenous control in the same sample.

\section{Protein extraction and Western blot}

Lysates of cells were prepared using lysis buffer from the Dual-Luciferase assay kit (Promega) according to the manufacturer's recommendations. The lysates were collected and centrifuged at $12,000 \mathrm{~g}$ for $10 \mathrm{~min}$ at $4^{\circ} \mathrm{C}$. The protein in the supernatants were pooled together and stored at $-80^{\circ} \mathrm{C}$ until concentration analyzed by the BCA Protein Assay Kit (Sangon, Shanghai, China). After being heated at $99^{\circ} \mathrm{C}$ for $5 \mathrm{~min}$ in loading buffer, equal volume of tissue lysates ( $40 \mu \mathrm{g}$ of protein) were then loaded for sodium dodecyl sulphate-polyacrylamide gel electophoresis (SDS-PAGE) analysis and subsequently electrotransferred from the gels onto a polyvinylidene difluoride (PVDF) membranes (Millipore, MA, USA). The transferred membranes were blocked with 5\% skim milk in Tris-buffered saline with $0.05 \%$ Tween (TBST) and washed six times in TBST. IDH1 and p53 proteins were detected by the rabbit polyclonal antibody for IDH1 (protein technology group, USA) or p53 (Santa Cruz, CA, 
USA). $\beta$-actin proteins were recognized by the $\beta$-actinspecific monoclonal mouse IgG (Santa Cruz, CA, USA). Antibodies were diluted according to the manufacture direction and were incubated overnight at $4^{\circ} \mathrm{C}$ followed by incubating with peroxidase-conjugated goat anti-rabbit immunoglobulin (Santa Cruz, CA, USA, 1:2000) in TBST for $1 \mathrm{~h}$. Signals were developed using enhanced chemiluminescent reagent (Pierce Biotechnology, Rockford, IL, USA). $\beta$-actin is used as the internal loading control. The band intensity was analyzed using Quantity One software (Bio-Rad, Hercules, and CA). Relative expression was calculated as the intensity ratio of target protein to that of $\beta$-actin.

\section{Tissue specimens and clinical data}

Fifty-one formalin-fixed, paraffin-embedded osteosarcoma biopsies (before the administration of neo-adjuvant chemotherapy) were collected according to the Chinese national ethical guidelines ('Code for Proper Secondary Use of Human Tissue', Chinese Federation of Medical Scientific Societies). Because of limitations in available tumor material and following up information, only 44 of these osteosarcoma tumor samples including 32(72.7\%) males and $12(27.3 \%)$ females with mean age $(\mathrm{M} \pm \mathrm{SD})$ of $25.25 \pm 13.61$ years (range 9-61) were amenable for use in this study. Patients were followed until death from disease, or until the latest clinical therapy at the end of this study. The mean following-up time $(\mathrm{M} \pm \mathrm{SD})$ were $4.26 \pm$ 1.99 years (range $0.5-9.0$ ). All patients consisted with the diagnostic criteria of osteosarcoma defined in the World Health Organization classification. Written informed consent was obtained from each patient before entering into this study. Clinical information was available in Table 1.

\section{Immunohistochemistry for biopsies}

Sections were cut from formalin-fixed, paraffin-embedded granulation tissue. They were hydrated through graded alcohols. For antigen unmasking, sections were treated in trypsin solution for $10 \mathrm{~min}$ at $37^{\circ} \mathrm{C}$. Sections were then washed with deionized water and incubated with $3 \% \mathrm{H}_{2} \mathrm{O}_{2}$ for $5 \mathrm{~min}$. They were incubated in antiIDH1 mAb (protein technology group, USA) or anti-p53 $\mathrm{mAb}$ (Santa Cruz, CA, USA) for $1 \mathrm{~h}$ at room temperature, followed by secondary antibody and peroxidase-conjugated strepavidin-biotin complex (Santa Cruz, CA, USA) at $37^{\circ} \mathrm{C}$ for $30 \mathrm{~min}$. Immunoreactivity was visualized with diaminobenzidine (DAB) (Zymed, South San Francisco, CA). Negative controls were obtained by omitting the primary antibody.

\section{Evaluation of immunohistochemistry}

The slides were evaluated under the microscope. The percentage of cells showing positive nuclear staining for p53 was calculated by reviewing the entire spot. For IDH1, cytoplasmic immunostaining was considered to be positive. The staining patterns were classified into scales on the percentage of cells with positive staining [26,27]: 0 , absence of nuclear (or cytoplasmic) stained cell; $1,<10 \%$ positive cells; $2,10-25 \%$ positive cells; $3,26-50 \%$ positive cells; $4,51-75 \%$ positive cells; $5,>75 \%$ positive cells. For statistical analysis, osteosarcoma patients were also grouped as either low-staining group (scale 0-3: positive staining $\leq 50 \%$ ) or high-staining group (scale 4,5 : positive staining $>50 \%$ ). Biopsy Stained less than $10 \%$ was considered as a negative result, while stained more than $10 \%$ was considered as a positive one. At least 5 separated foci of neoplastic infiltration in each biopsy were analyzed. Assessment of Immunostaining intensity was completed by three independent observers. Slides were scanned using a microscopy (Carl Zeiss AG, Germany), images were recorded using a digital camera (DC 500, Leica) and the Leica FW 4000 software and images were processed using Adobe Photoshop.

\section{Statistical analysis}

All statistical analyses were performed using the SPSS 13.0 software package for Windows (SPSS Inc., Chicago, IL, USA). The values for the description of the statistical significance of IDH1 or p53 expression in different osteosarcoma cell lines were calculated by independent, twotailed Student's t-tests after the Levine's Test for Equality of Variances. Mann-Whitney U was used for unnormal continuous variables. Categorical variables were analyzed by the Pearson Chis-square test and Fisher's exact test. Associations were assessed by Pearson correlation coefficient for normal data or Spearman's correlation coefficient for nonnormal data. Kaplan-Meier test was used for analysis of survival versus IDH1 and survival versus p53 expression. $P<0.05$ was considered as statistically significant. $P<0.01$ was considered as statistically highly significant.

\section{Results}

\section{IDH1 expresses higher in U2OS compared with in MG63}

Expression of IDH1 is specifically detected in the cytoplasm of both osteosarcoma cell lines U2OS and MG63 (Fig. 1). The expression of IDH1 mRNA is higher in U2OS than in MG63, and $P<0.01$ (Fig. 2). The western blotting result(Fig. 3A, Fig. 3C) shows that IDH1 is highly expressed in $\mathrm{U} 2 \mathrm{OS}(P<0.01)$, and these results corroborate the immunocytochemistry(Fig. 1).

\section{Expression of $\mathrm{p} 53$ in U2OS and MG63}

Consistent with data published previously [28,29]; our MG63 demonstrates no detectable p53 while U2OS demonstrates high expressed p53. The result is shown in Fig. 3B. 
Table 1: Clinical Features

\begin{tabular}{|c|c|c|}
\hline Features & Total(N) & Percentage \\
\hline \multicolumn{3}{|l|}{ Age(year) } \\
\hline$<12$ & 3 & $6.8 \%$ \\
\hline $13--20$ & 14 & $31.8 \%$ \\
\hline $21--30$ & 8 & $18.2 \%$ \\
\hline $31--40$ & 14 & $31.8 \%$ \\
\hline $41-$ & 5 & $11.4 \%$ \\
\hline \multicolumn{3}{|l|}{ Sex } \\
\hline Male & 32 & $72.7 \%$ \\
\hline Female & 12 & $27.3 \%$ \\
\hline \multicolumn{3}{|c|}{ Localization of primary tumor } \\
\hline Distal femur & 13 & $29.5 \%$ \\
\hline Proximal tibia & 11 & $25.0 \%$ \\
\hline Humerus & 3 & $6.8 \%$ \\
\hline Tibia diaphysis & 5 & $11.4 \%$ \\
\hline Femur diaphysis & 7 & $15.9 \%$ \\
\hline Other & 5 & $11.4 \%$ \\
\hline \multicolumn{3}{|l|}{ Histological type } \\
\hline Osteoblastic & 29 & $65.9 \%$ \\
\hline Small cell & 1 & $2.3 \%$ \\
\hline Chondroblastic & 6 & $13.6 \%$ \\
\hline Teleangetatic & 1 & $2.3 \%$ \\
\hline Round cell & 2 & $4.5 \%$ \\
\hline Fibroblastic & 4 & $9.1 \%$ \\
\hline Mixed & 1 & $2.3 \%$ \\
\hline \multicolumn{3}{|c|}{ Histological Rosen grade* } \\
\hline 1 & 5 & $11.3 \%$ \\
\hline 2 & 16 & $36.4 \%$ \\
\hline 3 & 16 & $36.4 \%$ \\
\hline 4 & 7 & $15.9 \%$ \\
\hline $1+2$ & 21 & $47.7 \%$ \\
\hline $3+4$ & 23 & $52.3 \%$ \\
\hline \multicolumn{3}{|l|}{ Metastasis } \\
\hline no & 23 & $53.3 \%$ \\
\hline lung & 17 & $38.6 \%$ \\
\hline other & 4 & $9.1 \%$ \\
\hline
\end{tabular}

*As described previously [30-32], Grade 1:<50\% tumor necrosis; Grade2: 50\% to 90\% tumor necrosis; Grade 3: > 90\% tumor necrosis;Grade 4: $100 \%$ tumor necrosis. $1+2$ : low grade; $3+4$ : high grade.

IDH1 correlates with histological Rosen grade and metastasis in clinical osteosarcoma biopsies

IDH1 mainly locates on the cytoplasm (Such as Fig. 1A, Fig. 4A, and Fig. 5A). It's positive expression was identified using immunohistochemistry in 40 of $44(90.9 \%)$ osteosarcoma tumors, of which 23 of 44 (52.2\%) exhibits high staining (Table 2). The average IDH1 immunostaining percentage is $53.57 \%$ (SD: $28.99 \%$, range from $8 \%$ to $100 \%$ ). The average score is 3.59 (SD: 1.22 , range from 1 to 5). IDH1 expresses higher in low Rosen grade osteosarcoma vs. high Rosen grade osteosarcoma [30-32] (Fig. 4, Fig. 5, Fig. 6, and Fig. 7). IDH1 correlates with metastasis 


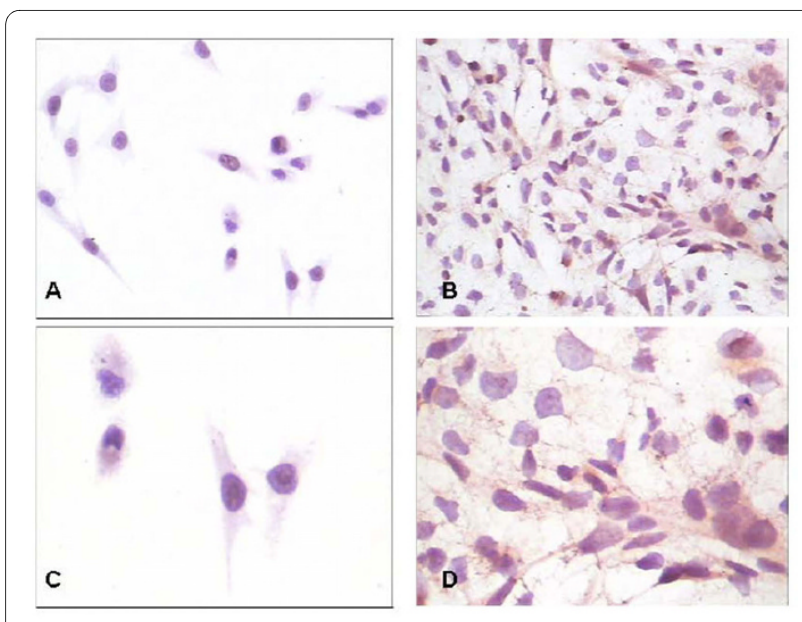

Figure 1 The immunocytochemistry of IDH1 in MG63 and U2OS IDH1 is specifically detected in the cytoplasm of both osteosarcoma cell lines MG63 and U2OS.(A) Expression of IDH1 in U2OS, $\times 200$; (B) Expression of IDH1 in MG63, $\times 200$; (C) Expression of IDH1 in U2OS, $\times 400$; (D) Expression of IDH1 in MG63, $\times 400$.

negatively $(P=0.016, \mathrm{r}=-0.361)$. There is no significant correlation between IDH1 expression and overall survival $(P=0.342)$ (Fig. 8).

\section{P53 correlates with histological Rosen grade, metastasis} and overall survival in clinical osteosarcoma biopsies

P53 mainly locates on the nuclear (Such as Fig 4B, Fig 4D), Its positive expression is identified using immunohistochemistry in 37 of 44 (84.1\%) osteosarcoma tumors, of which 19 of 44 (43.2\%) exhibits high staining (Table 2). The average p53 immunostaining percentage is

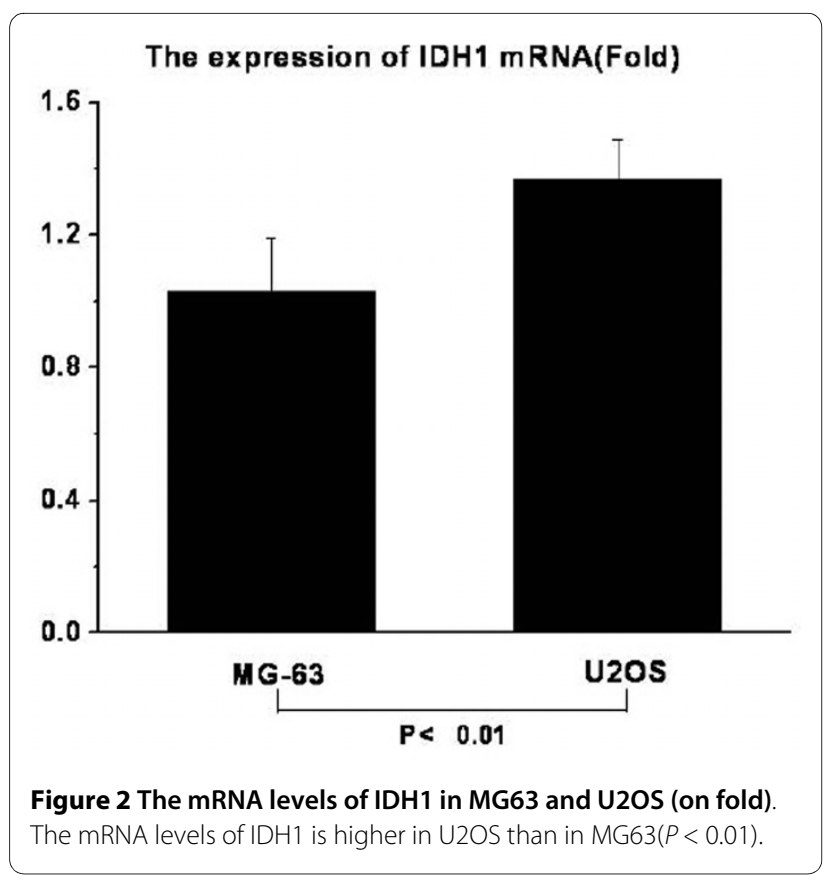

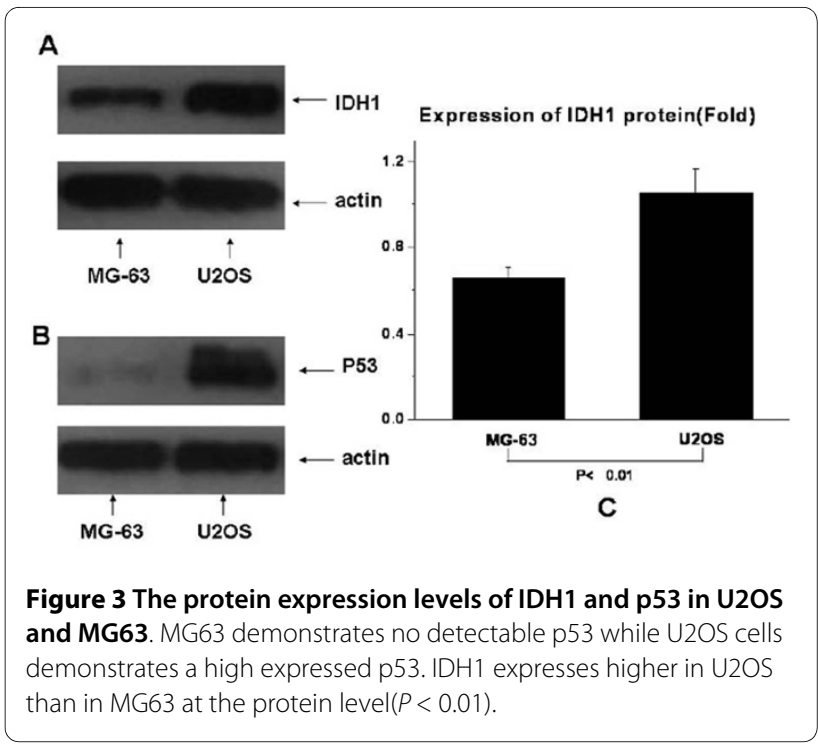

$47.25 \%(\mathrm{SD}: 28.82 \%$, range from $4.5 \%$ to $100 \%)$. The average score is 3.18 (SD: 1.35 , range from 1 to 5 ). P53 expresses higher in low Rosen grade osteosarcoma (Fig. 4, Fig. 5, Fig. 6, Fig. 7). P53 correlates with metastasis negatively $(\mathrm{P}=0.001, \mathrm{r}=-0.473)$. High-expression $\mathrm{p} 53$ patients have better survival than low-expression p53 patients do $(\mathrm{P}=0.019)$ (Fig. 9).

IDH1 correlates with p53 in clinical osteosarcoma biopsies There is no significant difference between IDH1 and p53 in clinical osteosarcoma biopsies. Positive correlation between IDH1 and p53 expression is demonstrated in our study (Table 2, Fig. 4, and Fig. 5).

\section{Discussion}

IDH1 catalyzes decarboxylation of isocitrate into alphaketoglutarate 16. Shechter et al. [17] described that activity of IDH1 is coordinately regulated with the cholesterol and fatty acid biosynthetic pathways, suggesting that IDH1 provides NADPH required by these pathways. It was described IDH1 appears to function as a tumor suppressor that, when mutationally inactivated, contributes to tumorigenesis [22]. IDH1 is likely to function as a tumor suppressor gene rather than as an oncogene [22]. IDH1, encoding two TCA enzymes, fumarate hydratase $(\mathrm{FH})$ and succinate dehydrogenase (SDH), has been found to sustain loss-of-function mutations in certain human tumors, which likewise contribute to tumor growth via stimulating the HIF-1a pathway and mutationally altering metabolic enzymes [33,34]. As IDH1 also catalyzes the production of NADPH, it is possible that a decrease in NADPH levels resulting from IDH1 mutation contributes to tumorigenesis through effects on cell metabolism and growth [17]. Zhao et al. [22] showed that mutation of IDH1 impairs the enzyme's affinity for its substrate and dominantly inhibits wild type IDH1 activity 
Table 2: The expression of IDH1 and P53 in osteosarcoma biopsies

\begin{tabular}{|c|c|c|c|c|c|c|c|c|}
\hline \multirow[t]{3}{*}{ Proteins* } & \multicolumn{7}{|c|}{ Expression** } & \multirow{2}{*}{$\begin{array}{c}\text { Positive } \\
\mathbf{N}^{* * *}\end{array}$} \\
\hline & 1 & 2 & 3 & 4 & 5 & Low & High & \\
\hline & N (\%) & N (\%) & N (\%) & N (\%) & N (\%) & N (\%) & N (\%) & N (\%) \\
\hline $\mathrm{IDH} 1$ & $4(9.1)$ & $2(4.5)$ & $15(34.1)$ & $10(22.7)$ & $13(29.5)$ & $21(47.7)$ & $23(52.2)$ & $40(90.9)$ \\
\hline P53 & $7(15.9)$ & 6 (13.6) & $12(27.3)$ & $10(22.7)$ & $9(20.5)$ & 25 (56.8) & 19 (43.2) & $37(84.1)$ \\
\hline
\end{tabular}

${ }^{*} \mathrm{P}<0.01(p=0.000) r=0.620$, IDH1 correlates with $\mathrm{P} 53$ positively; Spearman's rho.

** $P>3 / 40.05(P=0.316), I D H 1$ vs. P53; Mann-Whitney U.

*** P > 3/40.05(0.334), IDH1 vs. P53; Pearson Chis-square test;

with the formation of catalytically inactive heterodimers. Mutation of the IDH1 gene was strongly correlated with a normal cytogenetic status [21].

In this study, we firstly demonstrate that IDH1 is detected in U2OS with wild type p53 and MG63 with mutation p53 by immnohistochemistry, Realtime-PCR and Western Blotting. Intriguingly, our study demonstrates that IDH1 markedly increases in U2OS compare with MG63 not only in mRNA level but also in protein

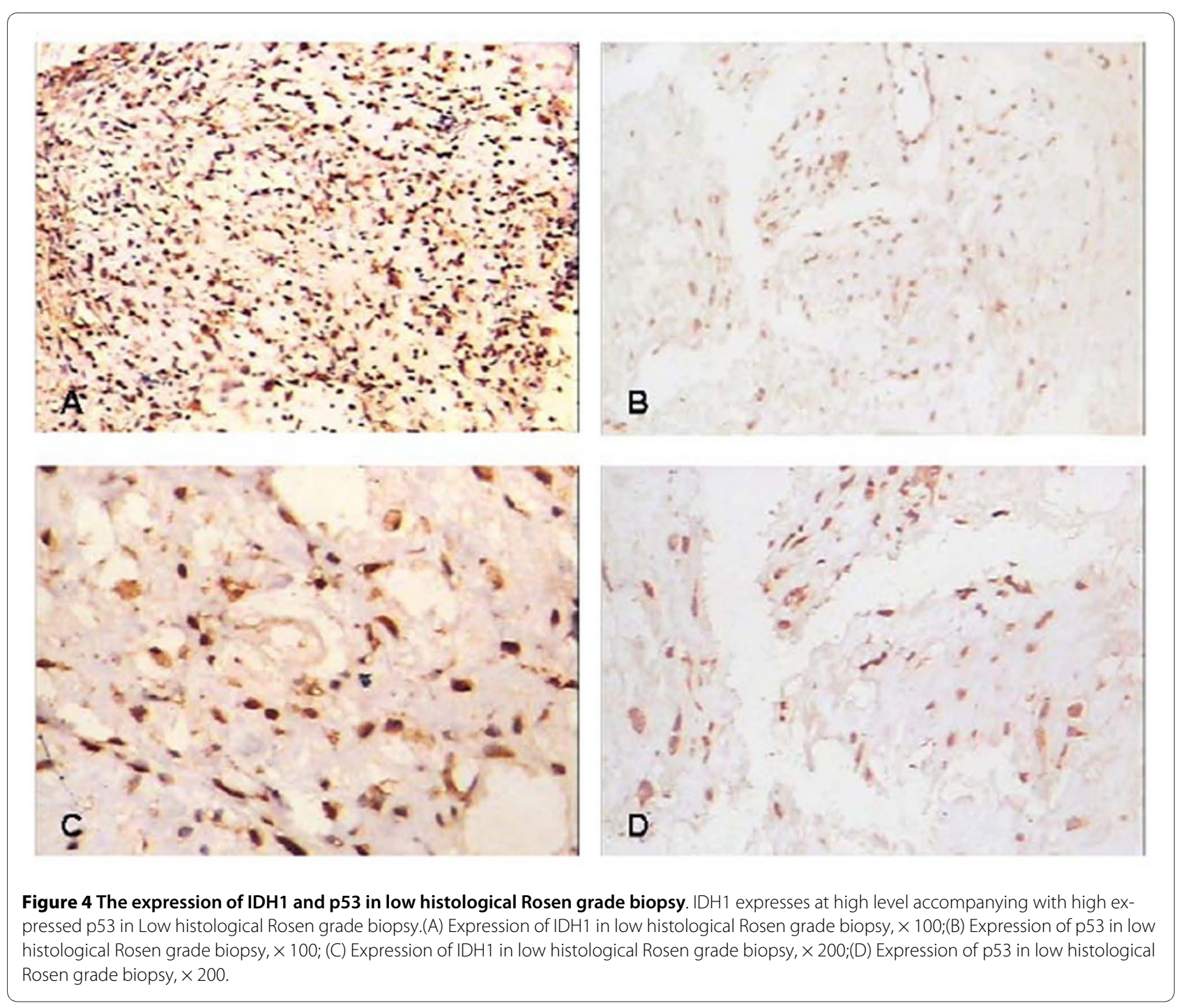




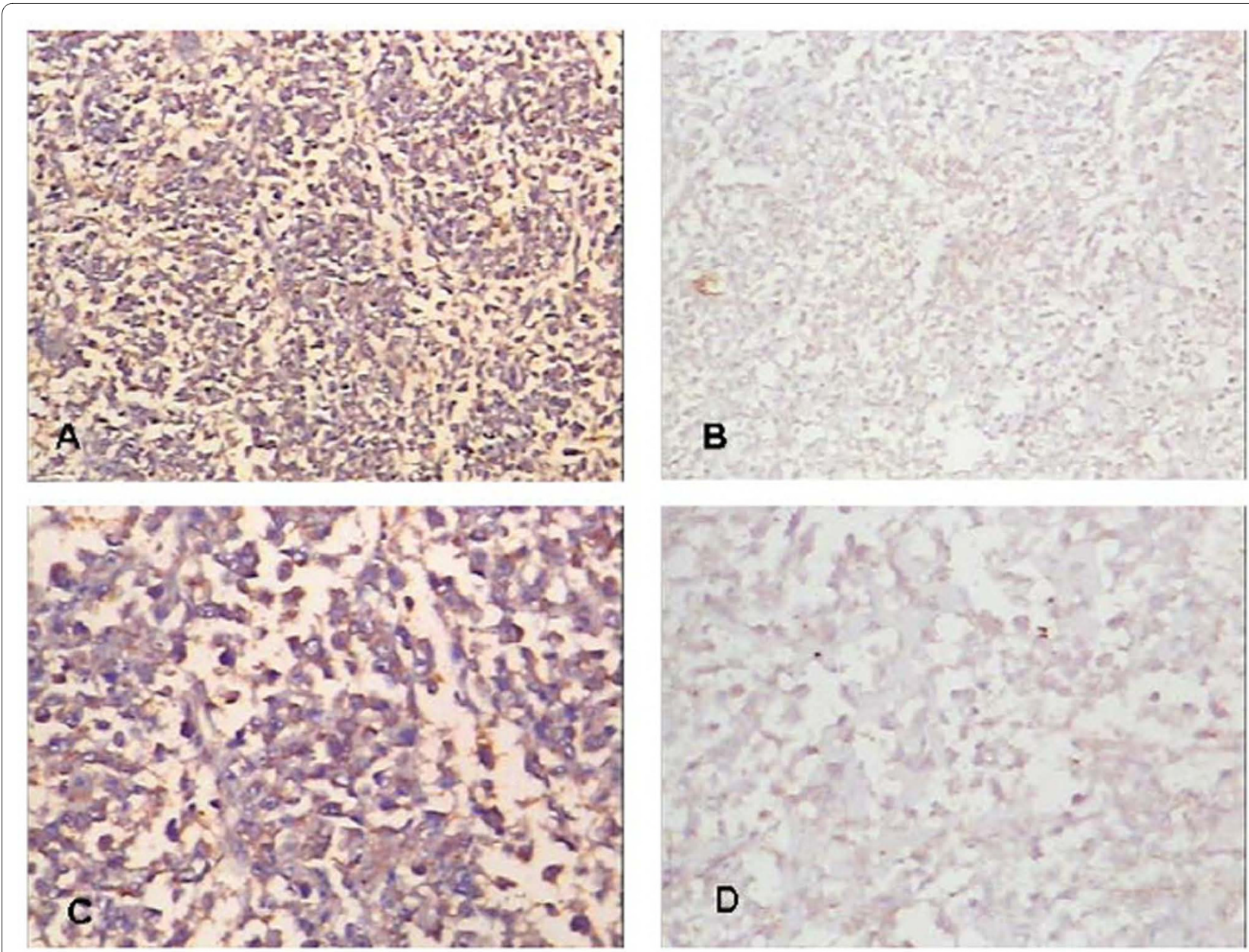

Figure 5 The expression of IDH1 and p53 in high histological Rosen grade biopsy. IDH1 expresses at low level accompanying with low expressed p53 in high histological Rosen grade biopsy. (A) Expression of IDH1 in high histological Rosen grade biopsy, $\times 100$;(B) Expression of p53 in high histological Rosen grade biopsy, $\times 100$; (C) Expression of IDH1 in high histological Rosen grade biopsy, $\times 200 ;(D)$ Expression of p53 in high histological Rosen grade biopsy, $\times 200$.

level. It is conceivable that the expression of IDH1 may relate to $\mathrm{p} 53$.

Human osteosarcoma cell line MG63 was found with Deletion and rearrangement of the p53 gene [35-37]. No Wild type p53 expression could be detected in this cell line. Our results are in accordance with the results of Masuda et al. [6] and Mulligan et al. [36] and indicate that inactivation of p53 is a common event in osteosarcoma development. In addition, we authenticate the wild type p53 in human osteosarcoma cell line U2OS in our study.

P53 is described as a tumor suppressor in many tumors. Culotta and Koshland [38] and Harris et al [39] gave an extensive account of its discovery and function as well as the use of p53 in cancer risk assessment. Activity of p53 ubiquitously lost in osteosarcoma either by mutation of the p53 gene itself or by loss of cell signaling upstream or downstream of p53 [40]. Xue et al. [41] reported that p53 inactive may be required for maintenance of aggressive tumors. Marion et al. [42] showed that p53 is critical in preventing the generation of human pluripotent cells from suboptimal parental cells. Harris and Hollstein [39] highlighted the clinical implications of changes in the p53 gene in the pathogenesis, diagnosis, prognosis, and therapy of human cancer. But, little is known about the combinatory role of p53 and IDH1 in OS cells. We are curious about the role of p53 and IDH1 in osteosarcoma.

Most studies addressing the immunohistochemical expression of IDH1 or p53 in biopsies have used a semiquantitative scoring approach of the staining results [4347], often with a $10 \%$ threshold for scoring a tumor as positive and with a $50 \%$ threshold for scoring a tumor as high expression level [48]. Using this approach, the immunoreactivity for IDH1 or p53 has been used to investigate its correlation with clinical features [47]. The staining pattern, and thus the difference in IDH1 reactivity, is highly different among individual tumors, showing 


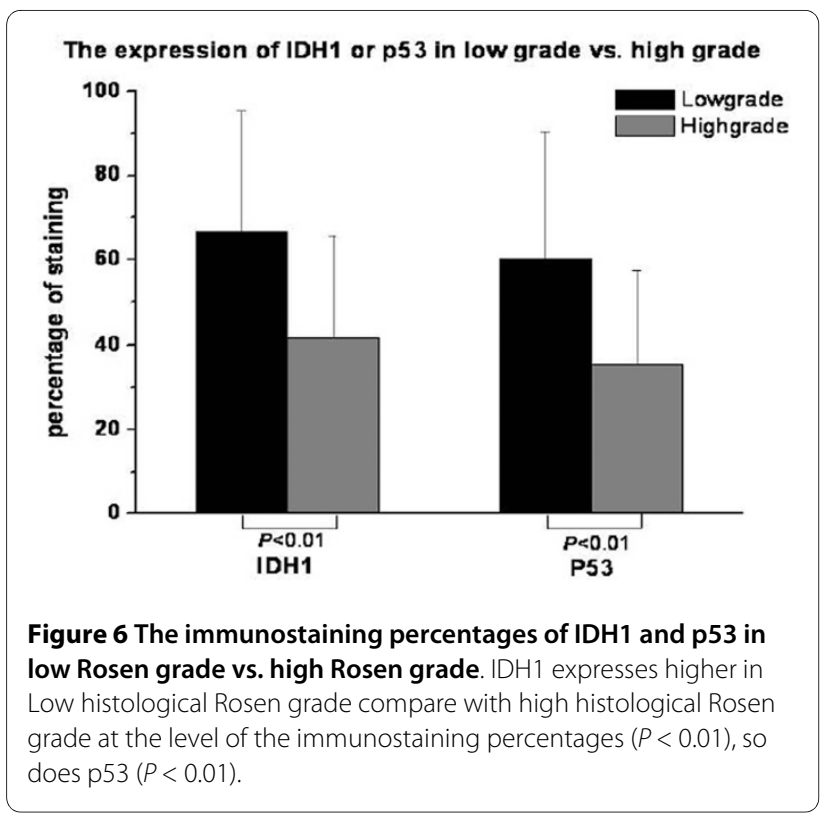

a range from $8 \%$ through $100 \%$ IDH1-positive tumor cells, while the P53, ranging from $5 \%$ to $100 \%$. In addition, the positive rate of IDH1 is $90.9 \%$, while the p53 is $84.1 \%$. The high staining rate of IDH1 is $52.2 \%$, while the p53 is $43.2 \%$. Furthermore, IDH1 expresses higher in patients with low histological Rosen grade. IDH1 correlates with metastasis negatively. There is no significant correlation between IDH1 expression and overall survival. In our study, lower IDH1 expression in higher Rosen grade may not convey mutation in the gene. To substitute, genetic studies of IDH1 gene alteration may be of value. The study is limited by the fact that there were only 44 patients and without intimate following up infor-

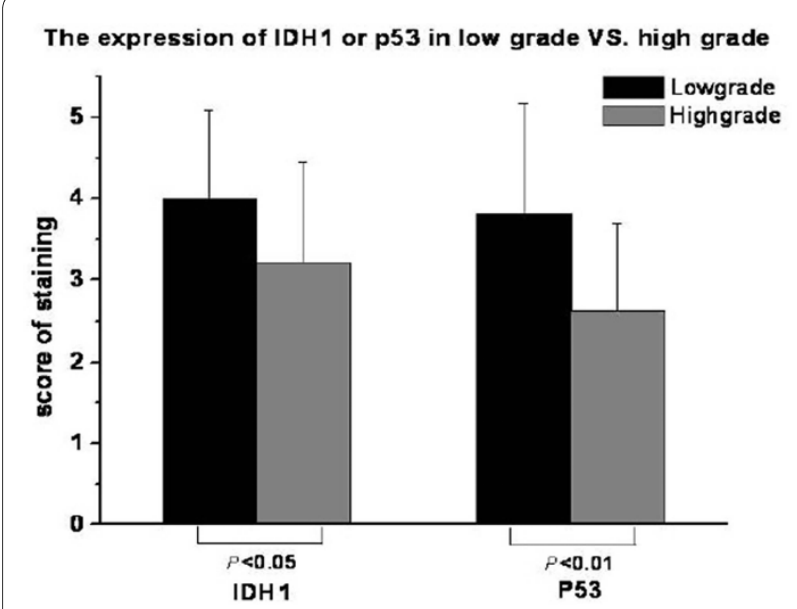

Figure 7 The immunostaining scores of IDH 1 and p53 in low Rosen grade vs. high Rosen grade. IDH1 expresses higher in Low histological Rosen grade compare with high histological Rosen grade at the level of the immunostaining scores $(P<0.05)$, so does p53 $(P<0.01)$.

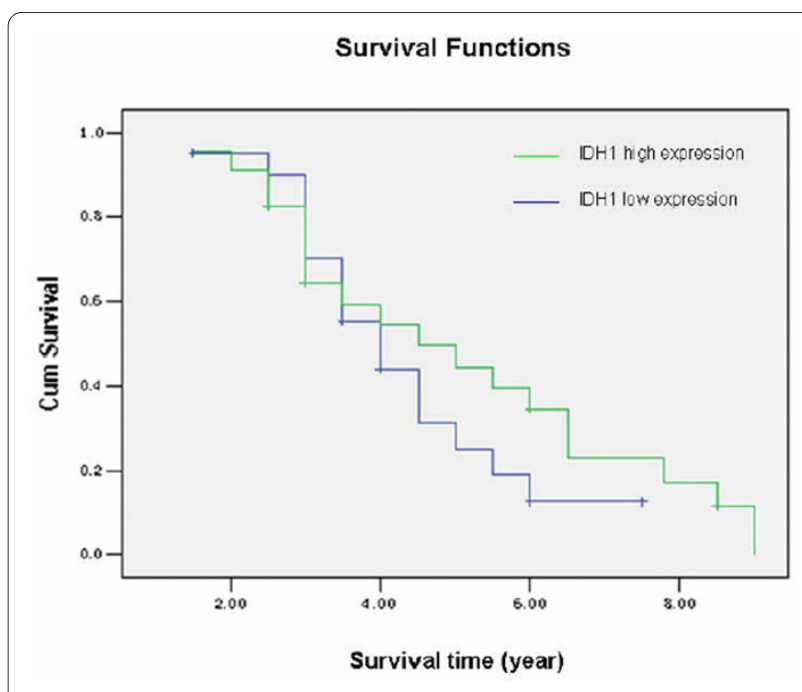

Figure 8 The relationship between IDH1 and survival. The IDH1 high expression group represents the osteosarcoma patients with $>50 \%$ IDH1 positive staining. Patients with $\leq 50 \%$ IDH1 positive staining are recorded as low-expression group. The survival time in the $x$ axis was given as years. There is no significant correlation between IDH1 expression and overall survival $(P=0.342)$

mation. However, it may, from the theoretical point of view, still be valuable to study the role of IDH1 in osteosarcoma. In accordance with former results, p53 in our osteosarcoma patients correlates with histological Rosen grade, metastasis and overall survival. In our study, the expression of IDH1 does not correlate some other clinical

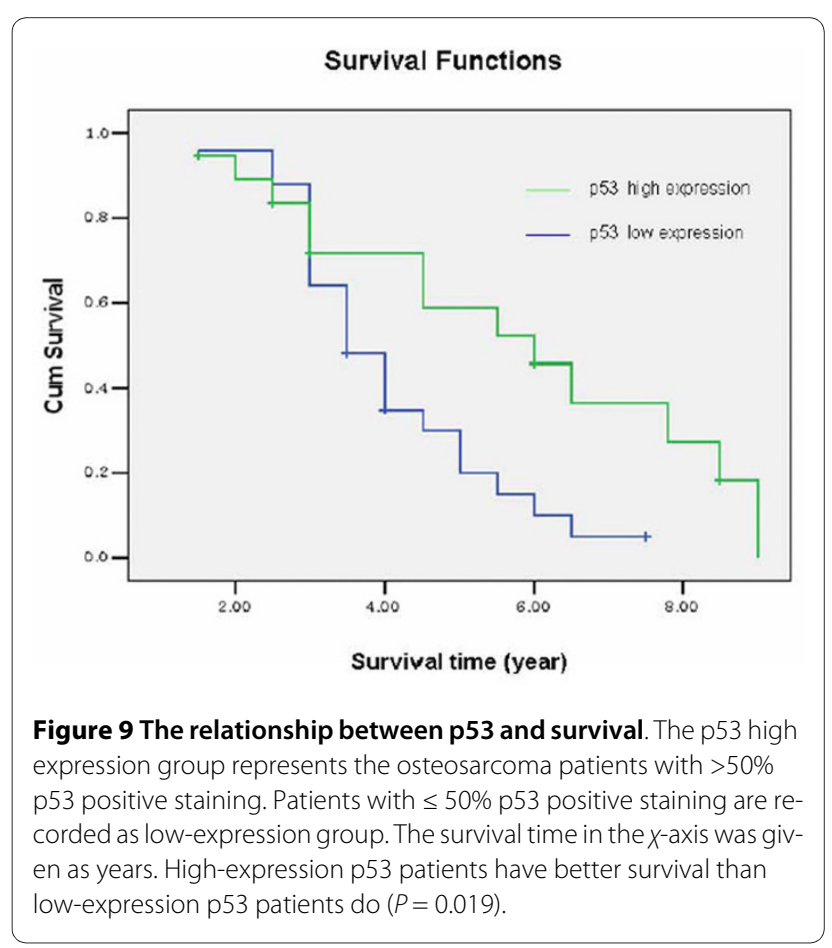


features such as age, localization of primary tumor and histological type.

Interestingly, patients in our study with High expression of IDH1 had a very high p53 expression in osteosarcoma biopsies, which is accordance with our result in osteosarcoma cell lines MG63 and U2OS. A recent study has shown IDH1 appears to function as a tumor suppressor contributes to tumorigenesis in part through induction of the HIF-1 pathway [22]. Parsons et al. [20] found that IDH1 mutations had a very high frequency of p53 mutation in human glioblastoma. Accumulation of functional p53 protein followed by p53-dependent apoptosis has been described in cultured cells exposed to hypoxia [49]. P53 inhibits HIF-1 dependent transcription and decrease the chances of normal cells surviving under hypoxia since the expression of most glycolytic enzymes is HIF-1 dependent [50]. It is conceivable that IDH1 may relate to p53 with the function of HIF-1.

\section{Conclusions}

IDH1 may correlate with p53 and be a biomarker for osteosarcoma correlate with histological Rosen grade and metastasis.

\section{List of abbreviations}

IDH1: isocitrate dehydrogenase 1; p53: transformationrelated protein 53; OS: osteosarcoma; PTEN: phosphates and tensin homolog; Rb: retinoblastoma gene; TCA: The citric acid cycle; SD: Std. Deviation.

\section{Competing interests}

The authors declare that they have no competing interests.

\section{Authors' contributions}

Hu X carried out most parts of the experiment; Qi BW, Fu T, Wu G, Zhou M, Luo $\mathrm{J}$ and $\mathrm{Xu} \mathrm{JH}$ participated in the experiment; Yu AX conceives the study project, organizes the whole study process, provides financial support, and finalizes the manuscript. All authors have read and approved the final manuscript.

\section{Acknowledgements}

We thank guorong Yu, zhenyu Pan, kai Deng, Shengxiang Tao for technical assistance. This work is supported by the grants from the Natural Science Foundation of China (No. 303131304), the health department Scientific Research Project of Hubei Province of China (No. 303121208).

\section{Author Details}

'Department of Orthopedics, Zhongnan Hospital of Wuhan University, No 169 Donghu Road, Wuchang District, 430071, Wuhan, China and 2Department of pathology, Zhongnan Hospital of Wuhan University, Wuhan, China

Received: 29 March 2010 Accepted: 7 May 2010

Published: 7 May 2010

\section{References}

1. Kager L, Zoubek A, Pötschger U, Kastner U, Flege S, Kempf-Bielack B, Branscheid D, Kotz R, Salzer-Kuntschik M, Winkelmann W, Jundt G, Kabisch $H$, Reichardt P, Jürgens H, Gadner H, Bielack SS: Primary metastatic osteosarcoma: presentation and outcome of patients treated on neoadjuvant Cooperative Osteosarcoma Study Group protocols. J Clin Oncol 2003, 21:2011-2018.

2. Ferguson WS, Goorin AM: Current treatment of osteosarcoma. Cancer Invest 2001, 19:292-315.
3. Overholtzer M, Rao PH, Favis R, Lu XY, Elowitz MB, Barany F, Ladanyi M, Gorlick R, Levine AJ: The presence of $\mathrm{p} 53$ mutations in human osteosarcomas correlates with high levels of genomic instability. Proceedings of the National Academy of Sciences of the United States of America 2003, 100:11547-11552.

4. Zheng Shui-er, Yso Yang, Dong Yang, Lin Feng, Zhao Hui, Shen Zan, Sun Yuan-jue, Tang Li-na: Down-regulation of ribosomal protein L7A in human osteosarcoma. J Cancer Res Clin Oncol 2009, 135:1025-1031.

5. Saleh HA, Jin B, Barnwell J, Alzohaili O: Utility of immunohistochemical markers in differentiating benign from malignant follicular-derived thyroid nodules. Diagn Pathol 2010, 26:5-9.

6. Masuda H, Miller C, Koeffler HP, Battifora H, Cline MJ: Rearrangement of the p53 gene in human osteogenic sarcoma. Proc Natl Acad Sci USA 1987, 84:7716-9.

7. Baker SJ, Fearon ER, Nigro JM, Hamilton SR, Preisinger AC, Jessup JM, vanTuinen $\mathrm{P}$, Ledbetter DH, Barker DF, Nakamura Y, White R, Vogelstein B: Chromosome 17 deletions and $\mathrm{p} 53$ gene mutations in colorectal carcinomas. Science 1989, 244:217-21

8. Miller G, Socci ND, Dhall D, D'Angelica M, DeMatteo RP, Allen PJ, Singh B, Fong Y, Blumgart LH, Klimstra DS, Jarnagin WR: Genome wide analysis and clinical correlation of chromosomal and transcriptional mutations in cancers of the biliary tract. Journal of Experimental \& Clinical Cancer Research 2009, 28:62.

9. Vousden KH, Lane DP: P53 in health and disease. Nat Rev Mol Cell Biol 2007 8:275-83.

10. Di Cristofano A, Pandolfi PP: The multiple roles of PTEN in tumor suppression. Cell 2000, 100:387-390.

11. Cantley LC, Neel BG, New insights into tumor suppression: PTEN suppresses tumor formation by restraining the phosphoinositide 3 kinase/AKT pathway. Proc Natl Acad Sci USA 1999, 96:4240-4245.

12. Hamada K, Sasaki T, Koni PA, Natsui M, Kishimoto H, Sasaki J, Yajima N, Horie Y, Hasegawa G, Naito M, Miyazaki J, Suda T, Itoh H, Nakao K, Mak TW, Nakano T, Suzuki A: The PTEN/PI3K pathway governs normal vascular development and tumor angiogenesis. Genes Dev 2005, 19:2054-2065.

13. Freeman SS, Allen SW, Ganti R, Wu J, Ma J, Su X, Neale G, Dome JS, Daw NC, Khoury JD: Copy number gains in EGFR and copy number losses in PTEN are common events in osteosarcoma tumors. Cancer 2008, 113:1453-61.

14. Ternovoi1 Vladimir V, Curiel David T, Smith Bruce F, Siegal Gene P: Adenovirus-mediated $\mathrm{p} 53$ tumor suppressor gene therapy of osteosarcoma. Laboratory Investigation 2006, 86:748-766.

15. Wadayama B, Toguchida J, Shimizu T, Ishizaki K, Sasaki MS, Kotoura Y, Yamamuro T: Mutation spectrum of the retinoblastoma gene in osteosarcoma. Cancer Res 1994, 54:3042-8.

16. Nekrutenko A, Hillis DM, Patton JC, Bradley RD, Baker RJ: Cytosolic isocitrate dehydrogenase in humans, mice, and voles and phylogenetic analysis of the enzyme family. Molec Biol Evol 1998, 15:1674-1684

17. Shechter I, Dai P, Huo L, Guan G: IDH1 gene transcription is sterol regulated and activated by SREBP-1 1 and SREBP- 2 in human hepatoma HepG2 cells: evidence that IDH1 may regulate lipogenesis in hepatic cells. J Lipid Res 2003, 44:2169-2180.

18. Memon AA, Chang JW, Oh BR, Yoo YJ: Identification of differentially expressed proteins during human urinary bladder cancer progression. Cancer Detect Prev 2005, 29:249-255.

19. Yan H, Parsons DW, Jin G, McLendon R, Rasheed BA, Yuan W, Kos I, BatinicHaberle I, Jones S, Riggins GJ, Friedman H, Friedman A, Reardon D, Herndon J, Kinzler KW, Velculescu VE, Vogelstein B, Bigner DD: IDH1 and IDH2 mutations in gliomas. New Eng J Med 2009, 360:765-773.

20. Parsons DW, Jones S, Zhang X, Lin JC-H, Leary RJ, Angenendt P, Mankoo P, Carter H, Siu I-M, Gallia GL, Olivi A, McLendon R, 21 others: An integrated genomic analysis of human glioblastoma multiforme. Science 2008, 321:1807-1812

21. Mardis ER, Ding L, Dooling DJ, Larson DE, McLellan MD, Chen K, Koboldt DC, Fulton RS, Delehaunty KD, McGrath SD, Fulton LA, Locke DP, 46 others: Recurring mutations found by sequencing an acute myeloid leukemia genome. New Eng J Med 2009, 361:1058-1066.

22. Zhao $S$, Lin $Y, X u$ W, Jiang $W$, Zha Z, Wang P, Yu W, Li Z, Gong L, Peng Y, Ding J, Lei Q, Guan K-L, Xiong Y: Glioma-derived mutations in IDH1 dominantly inhibit IDH1 catalytic activity and induce HIF-1-alpha. Science 2009, 324:261-265. 
23. Jeong Ji-Hak, Nakajima Hiroo, Magae Junji, Furukawa Chiharu, Taki Keiko, Otsuka Kensuke, Tomita Masanori, Lee In-Seon, Kim Cheorl-Ho, Chang Hyeun-Wook, Min Kwan-Sik, Park Kwang-Kyun, Park Kwan-Kyu, Chang Young-Chae: Ascochlorin activates p53 in a manner distinct from DNA damaging agents. Int J Cancer 2009, 124:2797-2803.

24. Saiki RK, Gelfand DH, Stoffel S, Scharf SJ, Higuchi R, Horn GT, Mullis KB, Erlich HA: Primer-directed enzymatic amplification of DNA with a thermostable DNA polymerase. Science 1988, 239:487-491.

25. Hellwinkel OJ, Müller A, Struve D, Hiort O: Influence of androgens and age on androgen receptor and 5 alpha-reductase II transcription. Eur J Endocrinol 2000, 143:217-225.

26. Ryu K, Choy E, Yang C, Susa M, Hornicek FJ, Mankin H, Duan Z: Activation of Signal Transducer and Activator of Transcription 3 (Stat3) Pathway in Osteosarcoma Cells and Overexpression of Phosphorylated-Stat3 Correlates with Poor Prognosis. J Orthop Res 2010 in press.

27. Wu L, Peng CW, Hou JX, Zhang YH, Chen C, Chen LD, Li Y: Coronin-1C is a novel biomarker for hepatocellular carcinoma invasive progression identified by proteomics analysis and clinical validation. J Exp Clin Cancer Res 2010 in press.

28. Ponten J, Saksela E: Two established in vitro cell lines from human mesenchymal tumors. Int J Cancer 1967, 2:434-47.

29. Heremans H, Billiau A, Cassiman JJ, Mulier JC, de Somer P: In vitro cultivation of human tumor tissues. II. Morphological and virological characterization of three cell lines. Oncology 1978, 35:246-52.

30. Huvos AG, Rosen G, Marcove RC: Primary osteogenic sarcoma: pathologic aspects in 20 patients after treatment with chemotherapy en bloc resection, and prosthetic bone replacement. Arch Pathol Lab Med 1977, 101:14-18.

31. Rosen G, Marcove RC, Caparros B, Nirenberg A, Kosloff C, Huvos AG: Primary osteogenic sarcoma: the rationale for preoperative chemotherapy and delayed surgery. Cancer 1979, 43:2163-2177.

32. Rosen G, Murphy ML, Huvos AG, Gutierrez M, Marcove RC: Chemotherapy, en bloc resection, and prosthetic bone replacement in the treatment of osteogenic sarcoma. Cancer 1976, 37:1-11.

33. MacKenzie ED, Selak MA, Tennant DA, Payne LJ, Crosby S, Frederiksen CM, Watson DG, Gottlieb E: Cell-permeating alpha-ketoglutarate derivatives alleviate pseudohypoxia in succinate dehydrogenase-deficient cells. Mol Cell Biol 2007, 27:3282-9.

34. Ingebretsen OC: Mechanism of the inhibitory effect of glyoxylate plus oxaloacetate and oxalomalate on the NADP-specific isocitrate dehydrogenase. Biochim Biophys Acta 1976, 452:302-9.

35. Lindström MS, Nistér M: Silencing of ribosomal protein $\mathrm{S} 9$ elicits a multitude of cellular responses inhibiting the growth of cancer cells subsequent to p53 activation. PLoS One 2010, 5:e9578.

36. Mulligan LM, Matlashewski GJ, Scrable HJ, Cavenee WK: Mechanisms of p53 loss in human sarcomas. Proc Natl Acad Sci USA 1990, 87:5863-7.

37. Chandar N, Billig B, McMaster J, Novak J: Inactivation of p53 gene in human and murine osteosarcoma cells. Br J Cancer 1992, 65:208-14.

38. Culotta E, Koshland DE Jr: P53 sweeps through cancer research. Science 1993, 262:1958-61.

39. Harris CC, Hollstein M: Clinical implications of the p53 tumor-suppressor gene. NEngl J Med 1993, 329:1318-27.

40. Bourdon JC, Fernandes K, Murray-Zmijewski F, Liu G, Diot A, Xirodimas DP, Saville MK, Lane DP: P53 isoforms can regulate p53 transcriptional activity Genes. Dev 2005, 19:2122-37.

41. Xue C, Haber M, Flemming C, Marshall GM, Lock RB, MacKenzie KL, Gurova KV, Norris MD, Gudkov AV: P53 determines multidrug sensitivity of childhood neuroblastoma. Cancer Res 2007, 67:10351-60.

42. Marion RM, Strati K, Li H, Murga M, Blanco R, Ortega S, Fernandez-Capetillo $\mathrm{O}$, Serrano M, Blasco MA: A p53-mediated DNA damage response limits reprogramming to ensure iPS cell genomic integrity. Nature 2009, 460:1149-1153.

43. Wadayama B, Toguchida J, Yamaguchi T, Sasaki MS, Yamamuro T: P53 expression and its relationship to DNA alterations in bone and soft tissue sarcomas. British Journal of Cancer 1993, 68:1134-1139.

44. Stefanou DG, Nonni AV, Agnantis NJ, Athanassiadou SE, Briassoulis E, Pavlidis N: p53/MDM-2 immunohistochemical expression correlated with proliferative activity in different subtypes of human sarcomas: a ten-year followup study. Anticancer Research 1998, 18:4673-4681.

45. Lonardo F, Ueda T, Huvos AG, Healey J, Ladanyi M: P53 and MDM2 alterations in osteosarcomas. Correlation with clinicopathologic features and proliferative rate. Cancer 1997, 79:1541-1547.
46. Matsuo T, Sugita T, Shimose S, Kubo T, Ishikawa M, Yasunaga Y, Ochi M: Immunohistochemical expression of promyelocytic leukemia body in soft tissue sarcomas. Journal of Experimental \& Clinical Cancer Research 2008, 27:73.

47. Ueda Y, Dockhorn-Dworniczak B, Blasius S, Mellin W, Wuisman P, Böcker W, Roessner A: Analysis of mutant P53 protein in osteosarcomas and other malignant and benign lesions of bone. Journal of Cancer Research and Clinical Oncology 1993, 119:172-178.

48. Naka T, Fukuda T, Shinohara N, Iwamoto Y, Sugioka Y, Tsuneyoshi M: Osteosarcoma versus malignant fibrous histiocytoma of bone in patients older than 40 years. A clinicopathologic and immunohistochemical analysis with special reference to malignant fibrous histiocytoma-like osteosarcoma. Cancer 1995, 76:972-984.

49. Graeber TG, Osmanian C, Jacks T, Houseman DE, Koch CJ, Lowe SW Giaccia AJ: Hypoxia-mediated selection of cells with diminished apoptotic potential in solid tumors. Nature 1996, 379:88-91.

50. Salnikow K, An WG, Melillo G, Blagosklonny MV, Costa M: Nickel-induced transformation shifts the balance between HIF-1 and p53 transcription factors. Carcinogenesis 1999, 20:1819-23.

doi: $10.1186 / 1756-9966-29-43$

Cite this article as: $\mathrm{Hu}$ et al., The expression and significance of IDH1 and p53 in osteosarcoma Journal of Experimental \& Clinical Cancer Research 2010 29:43

\section{Submit your next manuscript to BioMed Central and take full advantage of:}

- Convenient online submission

- Thorough peer review

- No space constraints or color figure charges

- Immediate publication on acceptance

- Inclusion in PubMed, CAS, Scopus and Google Scholar

- Research which is freely available for redistribution 